\title{
Potential of Dust and Soot from Air-Filters of Motor Vehicle Engines as a Forensic Tool: First Experimental Palynological Approach in India
}

\author{
Sandip More ${ }^{1}$, Kishore Kumar Thapa ${ }^{2}$ and Subir Bera ${ }^{1 *}$
}

${ }^{1}$ Centre of Advanced Study, Department of Botany, University of Calcutta, 35, Ballygunge Circular Road, Kolkata, India

${ }^{2}$ Department of Botany, Dinhata College, Cooch Bihar, India

\begin{abstract}
Dust and soot samples collected from air filters of motor cars and motor boats from three localities, namely Darjeeling, Murshidabad and the Sundarbans, West Bengal, India, each with its own characteristic vegetation type, were analysed for pollen and spore content to investigate their potentials as palynological traps. Pollen grains from high altitude vegetation (Alnus nepalensis, Ilex sp., Pinus sp., Primula sp., Rhododendron sp., Pteris sp., Asplenium sp., Duabanga sp.) were recovered from cars driven through Darjeeling to Kalimpong while pollen grains of mesophytic plants (Mangifera indica, Cocos nucifera, Borassus flabellifer, Parthenium hysterophorus, Azadirachta indica, Lantana camara) and mangroves (Sonneratia apetala, Avicennia sp., Acanthus ilicifolius, Bruguiera sp., Rhizophora mucronata, Heritiera fomes, Phoenix paludosa, Nypa fruticans) were recovered from the vehicles in the Murshidabad district and motor boats in the Indian Sundarbans respectively. Principal Components Analysis (PCA) revealed that pollen spectra from different vegetation zones form distinct groups, while dust/soot samples from areas of similar vegetation zone form a single group while Correspondence Analysis (CA) demonstrates that the dust/soot samples from a distinct vegetation zone and the recovered palynotaxa from these dust/soot samples from a single group. Palynoassemblage analysis, together with PCA and CA data, suggests that dust and soot from air filters of motor vehicle engines may be a reliable trap for palynomorphs, which may help to trace the localities through which vehicles in question have travelled.
\end{abstract}

Keywords: Forensic science; Pollen analysis; Dust and soot; Airfilter; Motor vehicle; India

\section{Introduction}

The use of spores and pollen grains to solve legal problems is well established and pollen grains have been used in forensic cases in Sweden [1], New Zealand [2-16], Australia [17,18], the United Kingdom [1923] and the United States of America [24-29], but in India to date their use has not even been considered as associative evidence. Generally, forensic palynology has already been used in solving criminal cases based on associated pollen/spore assemblages from soil, clothes, and footwear of a person (suspect/victim) found at a crime scene. Its main forensic value lies in providing associative evidence that may assist in proving or disproving a link between people or objects with places or with other people or objects.

Many agents, for example, spider webs [30-32], hair [22], clothes [33], packing materials [34], are known to trap pollen grains and may help in deciphering the pollen rain of a particular area. Soil and dirt are common elements in the majority of crime scenes. As such, they must be collected carefully because these elements often contain abundant pollen grains and spores [35]. Previously, Mildenhall [36] suggested that dust collected from the air filter of a car belonging to a victim may prove useful in linking the victim to the location where the crime occurred. But until now no data (case sensitive or experimental) has been available to substantiate this ascertion. The air filter of a vehicle removes particulate material from air drawn into an engine. It follows therefore that dirt found within an air filter of an engine represents only air borne particles, including soil and palynomorphs, that have been encountered during the passage of a vehicle under power through a particular area. Mud found on a stolen vehicle or on a vehicle used in a crime, could link the vehicle to the place from which it was stolen or link it to the scene of the crime. Similarly, dirt found associated with other objects or different types of vehicles (i.e., truck, car, bicycle, motorcycle, motorboat etc.) thought to be associated with a crime may also yield palynomorphs useful in linking those vehicles to a specific crime or a specific geographical location [37]. By using palynological analysis it is not difficult to obtain a precise indication of the surrounding vegetation and by inference other characteristics of the area including climate and altitude. The pollen rain in each region of the world is a snapshot of the vegetation of that region and becomes a "pollen print" which can be used to assist in identifying the region. Most of the published data so far are from places other than India and are case sensitive. In Indian judiciary the potential of plant components to intelligence and evidence remains to be established. Therefore, experimental provenance of palynomorphs study from different parameters (clothes, hairs, fur, air-filters of vehicles, dust, dart, soil, clay) needs to be developed in the laboratory, which may then aid in future forensic investigations. For this purpose, the present study is undertaken to develop an experimental database for potential use in forensic investigations in India.

\section{Materials and Methods}

\section{Study area and sample collection}

Dust and soot samples were taken from air filters of motor cars and motor boats powered by internal combustion engines from three

*Corresponding author: Subir Bera, Centre of Advanced Study, Department of Botany, University of Calcutta , Kolkata, India, Tel: +91-033-2461 5445 Extn. 297 (0); Fax: +91-033-2461 4849; E-mail: berasubir@yahoo.co.in

Received December 14, 2012; Accepted February 24, 2013; Published April 23 2013

Citation: More S, Thapa KK, Bera S (2013) Potential of Dust and Soot from AirFilters of Motor Vehicle Engines as a Forensic Tool: First Experimental Palynological Approach in India. J Forensic Res 4:177. doi:10.4172/2157-7145.1000177

Copyright: @ 2013 More S, et al. This is an open-access article distributed unde the terms of the Creative Commons Attribution License, which permits unrestricted use, distribution, and reproduction in any medium, provided the original author and source are credited. 
different vegetation zones of West Bengal: a high-altitude vegetation zone of the Himalayan region (Darjeeling), a mesophytic vegetation zone (Murshidabad district) and a halophytic mangrove vegetation zone (the Indian Sundarbans, South 24 parganas district). Samples were collected to investigate possible correlations with vegetation along routes through which the vehicles had travelled (Figure 1). Five soot samples (MBSS- 1, 2, 3, 4 and 5) were collected from five motor boats which had travelled through Pakhiralaya, Sajnekhali, Sudhanyakhali, Lothian Island, Kakdwip and adjoining areas of the Sundarbans $\left(21^{\circ} 13^{\prime}\right.$ $-22^{\circ} 40^{\prime} \mathrm{N}, 88^{\circ} 05^{\prime}-89^{\circ} 06^{\prime} \mathrm{E}$ ) of South 24 Parganas. Five dust samples (MCDD- 1, 2, 3, 4 and 5) were collected from five motor cars that had travelled from Kalimpong $\left(27^{\circ} 04^{\prime} \mathrm{N}, 8^{\circ} 35^{\prime} \mathrm{E}\right)$ to Darjeeling $\left(27^{\circ} 03^{\prime}\right.$ $\left.\mathrm{N}, 88^{\circ} 18^{\prime} \mathrm{E}\right)$, from Darjeeling to Siliguri $\left(26^{\circ} 42^{\prime} \mathrm{N}, 88^{\circ} 25^{\prime} \mathrm{E}\right)$ along the Tista valley and similarly samples (MCDM - 1, 2, 3, 4 and 5) were also collected from five vehicles which had travelled through the Dhulian $\left(24^{\circ} 68^{\prime} \mathrm{N}, 87^{\circ} 97^{\prime} \mathrm{E}\right)$, Jangipur ( $\left.24^{\circ} 28^{\prime} \mathrm{N}, 88^{\circ} 05^{\prime} \mathrm{E}\right)$, Berhampore ( $24^{\circ} 06^{\prime}$ $\left.\mathrm{N}, 8^{\circ} 19^{\prime} \mathrm{E}\right)$, Beldanga $\left(23^{\circ} 58^{\prime} \mathrm{N}, 8^{\circ} 20^{\prime} \mathrm{E}\right)$ areas of Murshidabad district. These samples were collected during April - May, 2012.

\section{Palynomorph recovery and preparation of samples}

Samples were collected from air filters in sterilised plastic bags and then analysed in the laboratory (Figure 2). Before analysis the samples were stored in tightly closed sterilised containers with a small amount of alcohol (70\%) to avoid microbial growth and then frozen.

The dust and soot samples were placed into $10 \mathrm{ml}$ test tubes and

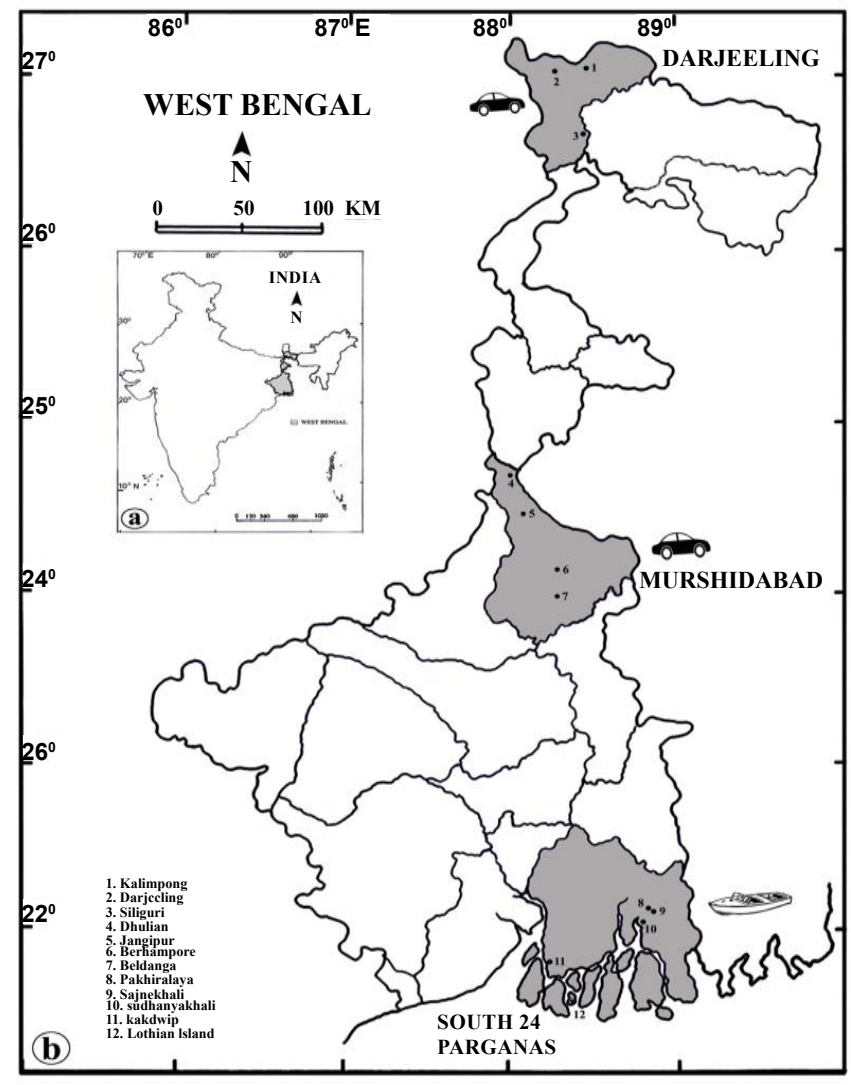

Figure 1: Location map of study area; a, Showing position of West Bengal in India; b, Map showing the routes travelled by sampling motor cars (Murshidabad and Darjeeling) and sampling motor boats (Sundarbans of South 24 Parganas), West Bengal.
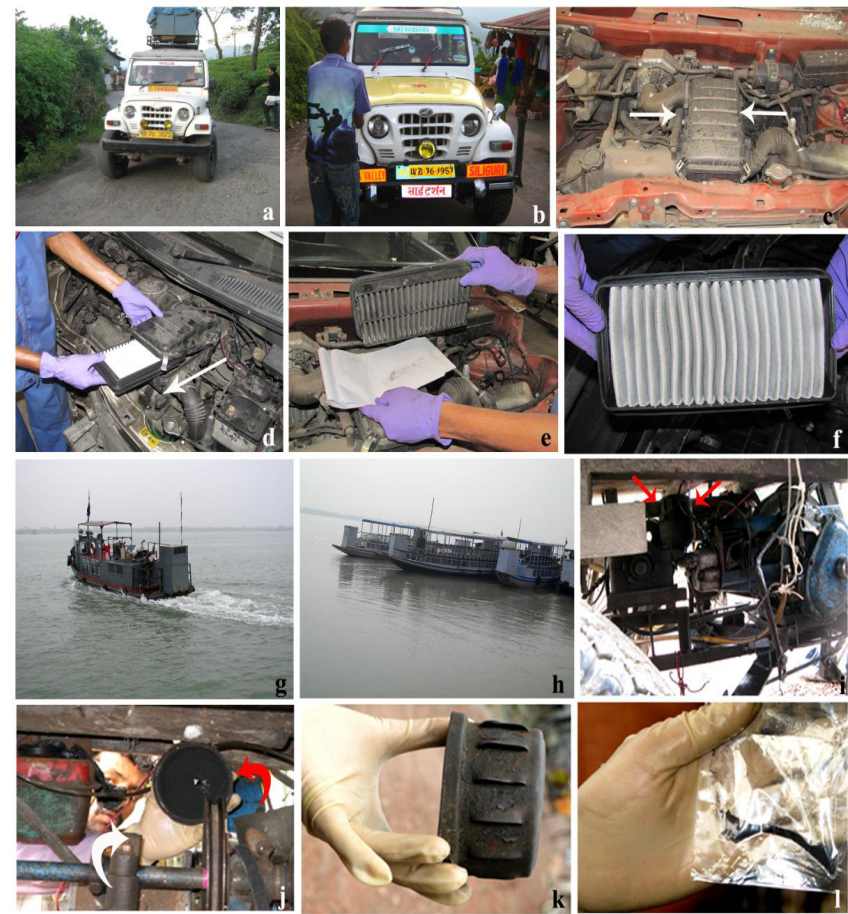

Figure 2: a) Sampling vehicle used on Kalimpong to Darjeeling route; b) Sampling vehicle used on Darjeeling to Siliguri route along the Teesta Valley; c, d) Position of air-filters in an engine of a motor car (white arrow) driving along the Darjeeling to Siliguri route; e) Collecting dust samples from the airfilter of a motor car; f) An air-filter of a motor car; g, h) Photographs of motor boats travelling around different islands of the Sundarbans (West Bengal); i) Red arrows indicate the position of the air-filter in an engine of motor boat; j) The inside view of an air-filter (red arrow) from a motor boat; k) An air-filter of motor boat; I, Collected soot samples from motor boats in plastic bag.

washed using distilled water by centrifugation and decantation to remove alcohol. $10 \%$ potassium hydroxide $(\mathrm{KOH})$ solution was added to the residue, warmed $\left(70^{\circ} \mathrm{C}\right)$ for $10-15$ minutes and stirred occasionally. This step breaks up the matrix (deflocculation) and dissolves humic materials, producing a dark brown solution. The residue was washed again using distilled water by centrifugation and decantation. Next, 0.1 $\mathrm{ml}$ solution of sodium pyrophosphate was added, stirred and placed in boiling $\left(100^{\circ} \mathrm{C}\right)$ water bath for $10-20$ minutes, centrifuged for 5 minutes and then decanted. The process was repeated twice. Distilled water was then added, stirred, centrifuged and finally decanted. This step is usually required only for soil samples in order to remove clay (fine mineral particles, mainly silica) as a high concentration of clay on prepared slides causes cloudiness and hinders pollen identification. After that $10 \%$ hydrochloric acid $(\mathrm{HCl})$ was added to the chemically treated dust samples from the air filters of the motor cars and kept for 24 hours. These were then stirred, centrifuged using distilled water at $3000 \mathrm{rpm}$ for 5-6 minutes and finally the supernatant was decanted. The process was repeated twice. This step removes carbonates which can cause a reaction with the reagent used in the last step which can be potentially dangerous to the user [19]. But the soot samples from the air filters of the motor boats from the Sundarbans were treated with organic solvent mixture (ethanol and chloroform in v/v 1:1 ratio) and then centrifuged three times using distilled water. The samples were then treated with $40 \%$ hydrofluoric acid. Hydrofluoric acid was added and placed in a boiling $\left(100^{\circ} \mathrm{C}\right)$ water bath for $15-20$ mins. Distilled water was then added, stirred, centrifuged and finally decanted. Then 
Citation: More S, Thapa KK, Bera S (2013) Potential of Dust and Soot from Air-Filters of Motor Vehicle Engines as a Forensic Tool: First Experimental Palynological Approach in India. J Forensic Res 4:177. doi:10.4172/2157-7145.1000177

residue was treated with acetolysis mixture (acetic anhydride and concentrated sulfuric acid in $\mathrm{v} / \mathrm{v}=9: 1)$. Acetolysis removes cellulose, a common plant polysaccharide $(1,3,12,26,36,38)$. The solution was placed in a boiling $\left(100^{\circ} \mathrm{C}\right)$ water bath for $4.0-4.5$ minutes, centrifuged and finally decanted. Slides were prepared using the method of Horrocks [12].

\section{Identification, counting of palynomorphs and statistical analysis}

A minimum of 150-200 palynomorphs were counted for each sample [16]. Principal Components Analysis (PCA) and Correspondence Analysis (CA) were performed with the palynological data from each sample collected from the three different regions of West Bengal, India. Light photomicrography of the different morphotypes was carried out using Zeiss Axioskop-2 microscope with an image analysing kit. Identification of the different spores and pollen grains was carried out through consultation of reference slides prepared and stored in the Palaeobotany-Palynology Laboratory, Department of Botany, University of Calcutta. Published literature was also consulted during identification of certain taxa.

\section{Results and Discussion}

The pollen spectra of soot samples collected from the air filters of motor boats in the Indian part of the Sundarbans is dominated by mangrove and associated species of the Indian Sundarbans such as Avicennia sp. (9.57-14.87\%), Sonneratia apetala (7.58-13.89\%), Xylocarpus sp. (6.98-14.76\%), Rhizophora mucronata (5.93-11.83\%), Phoenix paludosa (4.54-10.0\%), Excoecaria agallocha (4.67-8.12\%), Porteresia sp. (3.76-9.35\%), Ceriops sp. (2.98-7.78\%), Bruguiera sp. (2.90-8.27\%), Aegialitis sp. (0.54-4.91\%), Acanthus ilicifolius (1.19$3.12 \%)$, Nypa fruticans (0-3.87\%), Aegiceras sp. (0-3.12\%), Kandelia sp. (0-1.85\%), Derris sp. (0-2.41\%), Heritiera fomes. (0-0.91\%) along with pollen grains of Poaceae (1.30-3.98\%), Cheno-ams (1.03-3.27\%), Tamarix sp. (0-4.35\%), Tamarindus indica (0-3.87\%), Asteraceae (0.17$3.12 \%)$, Caesalpinia sp. (0.64-2.49\%), Azadirachta indica (0-3.21\%), Heliotropium sp. (0-2.12\%), Clerodendrum sp. (0-2.19\%), Diospyros sp. (0-1.60\%) and Barringtonia sp. (0-1.67\%) (Figure 3).

Pollen grains from angiosperm trees of Mangifera indica (7.7612.98\%), Alstonia sp. (3.18-11.52\%), Azadirachta indica (0.86-8.21\%), Plumeria sp. (0.59-5.19\%), Bombax sp. (2.11-4.21\%), Terminalia sp. (2.01-4.94\%), Delonix sp. (1.07-5.71\%), Peltophorum sp. (0-5.29\%), Syzygium cumini (0-6.31\%), Psidium guajava (0-6.91\%), Shorea robusta (0-5.27\%), Barringtonia sp. (0-4.28\%), Butea sp. (0-4.22\%), Lagerostroemia sp. (0-4.38\%), Eucalyptus sp. (0-3.68\%) were recovered from vehicles in Murshidabad. Also palynomorphs of the common road side herb, Argemone sp. (0-6.09\%) and shrub, Lantana camara (0-9.37\%) along with pteridophytic spores of Christella sp. (0-6.26\%) were recorded. Palm trees such as Cocos nucifera (6.49-10.21\%),

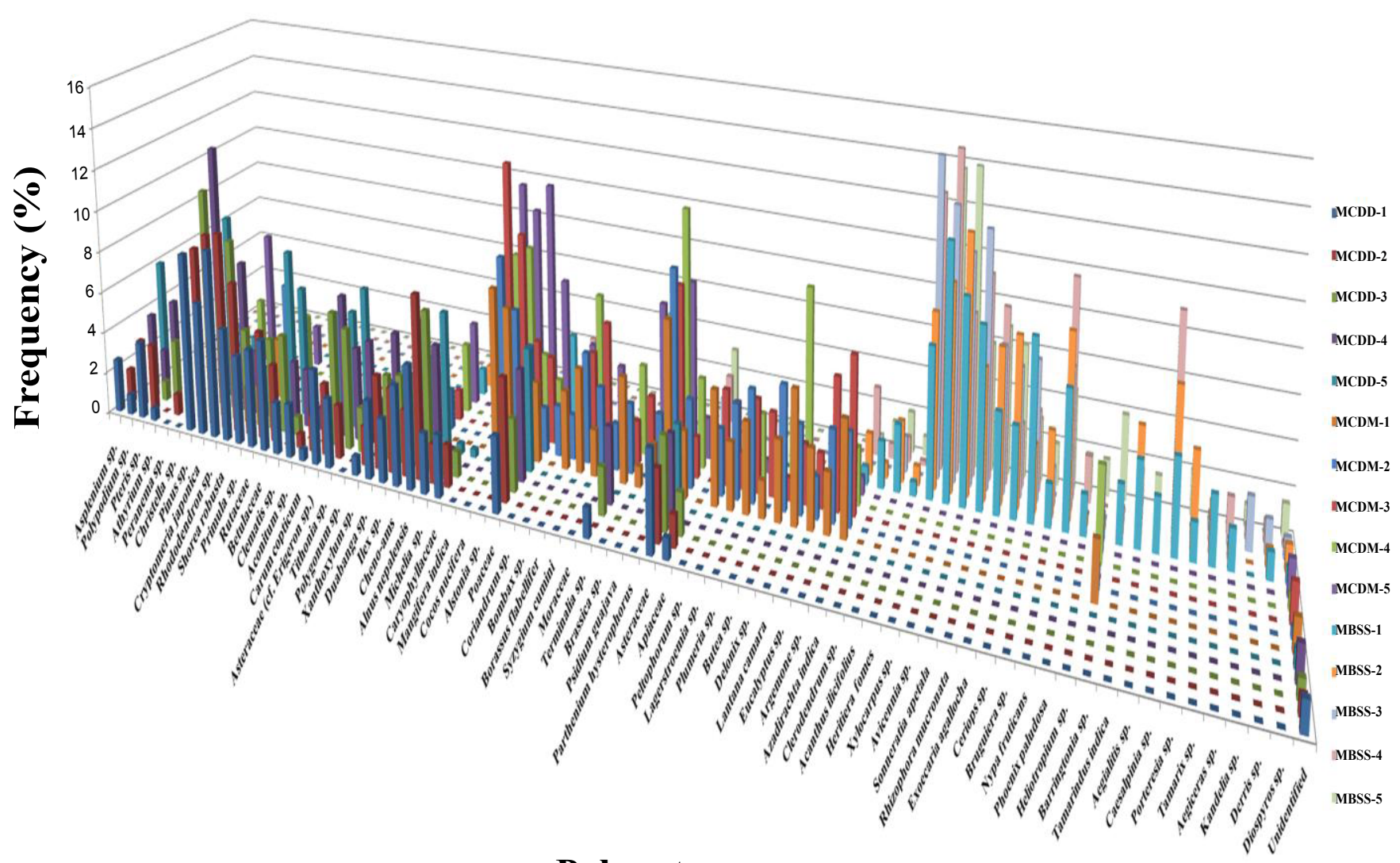

Palynotaxa

Figure 3: Pollen spectra of the dust and soot samples from air filters of motor cars and motor boats of Darjeeling, Murshidabad and Sundarbans, West Bengal. (MCDD=Motor car dust of Darjeeling, MCDM=Motor car dust of Murshidabad and MBSS=Motor boat soot of Sundarbans). 
Borassus flabellifer (1.89-7.10\%) and the common weed Parthenium hysterophorus $(7.98-11.90 \%)$ were found in abundance along with pollen grains of Poaceae (2.12 - 7.03\%), Asteraceae (1.91-4.21\%), Cheno-ams (1.45-3.96\%), Brassica sp. (0-6.89\%), Coriandrum sp. (0 $2.37 \%)$, Moraceae $(0-2.18 \%)$ in dust samples taken from the vehicles in the Murshidabad district (Figure 3).

The spore-pollen spectra of dust samples taken from the vehicles from the Darjeeling region of West Bengal (Figure 3) reveal a high frequency of Rhododendron sp. (3.28-9.45\%), Alnus nepalensis (5.438.56\%), Asteraceae (cf. Erigeron sp., 3.38-6.78\%), Poaceae (3.395.74\%), Tithonia sp. (2.53-6.90\%), Betulaceae (3.01-6.23\%), Shorea robusta (1.89-7.19\%), Rutaceae (0-7.89\%), Duabanga sp. (3.59-5.55\%), other Asteraceae (3.32-4.65\%), Cheno-ams (2.91-4.67\%), Ilex sp. (1.525.94\%), Primula sp. (0-4.22\%), Carum copticum (0-5.45\%), Polygonum sp. (0-4.89\%), Michelia sp. (0.49-2.80\%), Terminalia sp. (0-3.56\%), Xanthoxylum sp. (0-2.63\%), Caryophyllaceae (0-2.89\%), Clematis sp. (0-2.78\%), Apiaceae (0-1.96\%), Aconitum sp. (0-2.54\%) along with coniferous plants of Pinus sp. (8.49-12.73\%), Cryptomeria japonica (3.86-9.27\%) and pteridophytic spores of Pteris sp. (0.95-5.79\%), Asplenium sp. (0-5.95\%), Polypodium sp. (0-3.25\%), Peranema sp. (0$2.65 \%)$, Athyrium sp. (0-3.12\%).

Principal Components Analysis (PCA) is a variable reduction procedure. It is particularly useful when a number of variables are present and there is some redundancy in those variables. Here PCA was applied to the percentage frequency data of the 74 palynotaxa retrieved from 15 motor vehicle air-filter samples collected from three different phytoecological regions of West Bengal using the statistical program Statistica 6. This revealed the interrelationships of the different samples. The PCA biplots of the 15 samples and 74 palynotaxa are presented in Figure $4 \mathrm{a}$ and $4 \mathrm{~b}$. In the first two principal components, variance on axis 1 and axis 2 accounts for $35.42 \%$ and $30.18 \%$ respectively. On the biplot of the principal component scores of the 15 samples studied, the samples collected from Murshidabad (MCDM 1,2,3,4, and 5) showed a positive loading on axis 1 whereas samples collected from Darjeeling (MCDD 1, 2, 3, 4 and 5) showed the highest positive loadings on axis 2. Interestingly the palynotaxa recovered from the samples collected from the Darjeeling district also show the highest positive loadings on axis 2 (Figure $4 \mathrm{~b}$ ). In contrast, samples from the Sunderbans (MBSS $1,2,3,4$, and 5) formed a distinct group on axis 2. Correspondingly, palynotaxa retrieved from motorboat samples in the Sunderbans have distinguished themselves by forming a group on axis 2 (Figure $4 \mathrm{~b}$ ).

When we compared the results of the above-mentioned two PCA ordinations for the 15 samples studied of motor vehicle air-filter and 74 palynotaxa recovered from them, it was observed that the 15 samples can be distinctly placed into 3 groups as also revealed by their 3 distinct palynoassemblages. Some plants such as Asteraceae, Poaceae and Shorea robusta could not be grouped due to their presence in most of the samples.

Correspondence analysis (CA) is an ordination method. For comparing associations containing counts of taxa or counted taxa across associations, CA is the more appropriate analysis. It is a potential tool to visualize the links between the categories of two qualitative variables. Here CA was applied to the percentage frequency data of the 74 palynotaxa retrieved from 15 motor vehicle air-filter samples collected from three different phytoecological regions of West Bengal using the statistical program XLSTAT 2012 (Figure 5). In the CA symmetric plot along axes 1 and 2 (73.47\%), 74 types of palynotaxa and $15 \mathrm{dust} /$ soot samples formed three different groups with maximum variance along Axis 1 and Axis 2 as 38.46\% and 35.01\% respectively
(Figure 5). Dust samples from Darjeeling (MCDD-1,2,3,4 and 5) formed a distinct group in association with pollen grains of Asplenium sp.( T-1), Polypodium sp. (T-2), Pteris sp. (T-3), Athyrium sp. (T-4), Peranema sp. (T-5), Christella sp. (T-6), Pinus sp. (T-7), Cryptomeria japonica (T-8), Rhododendron sp. (T-9), Primula sp. (T-11), Rutaceae (T-12), Betulaceae (T-13), Clematis sp. (T-14), Aconitum sp. (T-15), Carum copticum (T-16), Asteraceae (cf. Erigeron sp.); T-17, Tithonia sp. (T-18), Polygonum sp. (T-19), Xanthoxylum sp. (T-20), Duabanga sp. (T-21), Ilex sp. (T-22), Alnus nepalensis (T-24), Michelia sp. (T-25), Caryophyllaceae (T-26) which resembles the high altitude vegetation of north eastern Himalaya. Soot samples from Sundarbans (MBSS$1,2,3,4$ and 5) also formed a distinct different group along with pollen grains of mangrove dominated vegetation such as Clerodendrum sp. (T-51), Acanthus ilicifolius (T-52), Heritiera fomes (T-53), Xylocarpus sp. (T-54), Avicennia sp. (T-55), Sonneratia apetala (T-56), Rhizophora mucronata (T-57), Exoecaria agallocha (T-58), Ceriops sp. (T-59), Bruguiera sp. (T-60), Nypa fruticans (T-61), Phoenix paludosa (T-62), Heliotropium sp. (T-63), Aegialitis sp. (T-66), Porteresia sp. (T-68), Tamarix sp. (T-69), Aegiceras sp. (T-70), Kandelia sp. (T-71), Derris sp. (T-72). Pollen grains of mesophytic vegetation viz., Mangifera indica (T-27), Cocos nucifera (T-28), Alstonia sp. (T-29), Coriandrum sp. (T31), Bombax sp. (T-32), Borassus flabellifer (T-33), Syzygium cumini (T-34), Brassica sp. (T-37), Psidium guajava (T-38), Parthenium hysterophorus (T-39), Peltophorum sp. (T-42), Lagerstroemia sp. (T43), Plumeria sp. (T-44), Butea sp. (T-45), Delonix sp. (T-46), Lantana camara (T-47), Argemone sp. (T-49) formed another group with dust samples collected from Murshidabad. Pollen grains of Shorea robusta (T-10), Cheno-ams (T-23), Poaceae (T-30), Terminalia sp. (T-36), Asteraceae (T-40), Azadirachta indiac (T-50), Barringtonia sp. (T-64) didn't form any group in CA symmetric plot because these pollen taxa were common to the dust/soot samples from Darjeeling, Murshidabad and Sundarbans of West Bengal.

Different type of conveyances such as motorcycle, motorized boat, bus, truck, private car or public taxi may be used in a crime or may be stolen. Pollen grains and spores are almost everywhere in the air or as re-suspended particles deposited in surface soil. These palynomorphs may be attached to different parts of a vehicle and could be useful in linking the conveyances to places relating to the crime. For the present investigation we have chosen three different vegetation zones in West Bengal, India i.e., Sundarbans, Murshidabad and Darjeeling. The Sundarbans are the largest mangrove forest tracts located in the Gangetic delta on the southern parts of West Bengal. Islands of the Sundarbans are dominated by mangrove plants and the only way to access the area is by boat. The Sundarbans flora is characterised by the abundance of Heritiera fomes, Excoecaria agallocha, Ceriops decandra and Sonneratia apetala, all of which occur prominently throughout the area. New forest accretions are often conspicuously dominated by Sonneratia apetala and tidal forests. Among palms, Phoenix paludosa and Nypa fruticans are well distributed [39, 40]. The recovery of a high frequency of pollen of true mangroves viz., Sonneratia apetala, Acanthus ilicifolius, Nypa fruticans, Bruguiera sp., Ceriops sp., Excoecaria agallocha, Rhizophora mucronata, Avicennia sp., Xylocarpus sp., Heritiera fomes, Phoenix paludosa, Aegialitis sp., Aegiceras sp., Kandelia sp. from the vehicles in the Sundarbans region suggests a characteristic deltaic mangrove halophytic vegetation and the sampling route through Pakhiralaya, Sajnekhali, Sudhanyakhali, Lothian Island and Kakdwip in the Sundarbans region falls within a tropical mangrove forest (Figure 6).

Murshidabad has moist tropical mesophytic evergreen vegetation and there are fruit bearing trees of various types but what the district 
Citation: More S, Thapa KK, Bera S (2013) Potential of Dust and Soot from Air-Filters of Motor Vehicle Engines as a Forensic Tool: First Experimental Palynological Approach in India. J Forensic Res 4:177. doi:10.4172/2157-7145.1000177

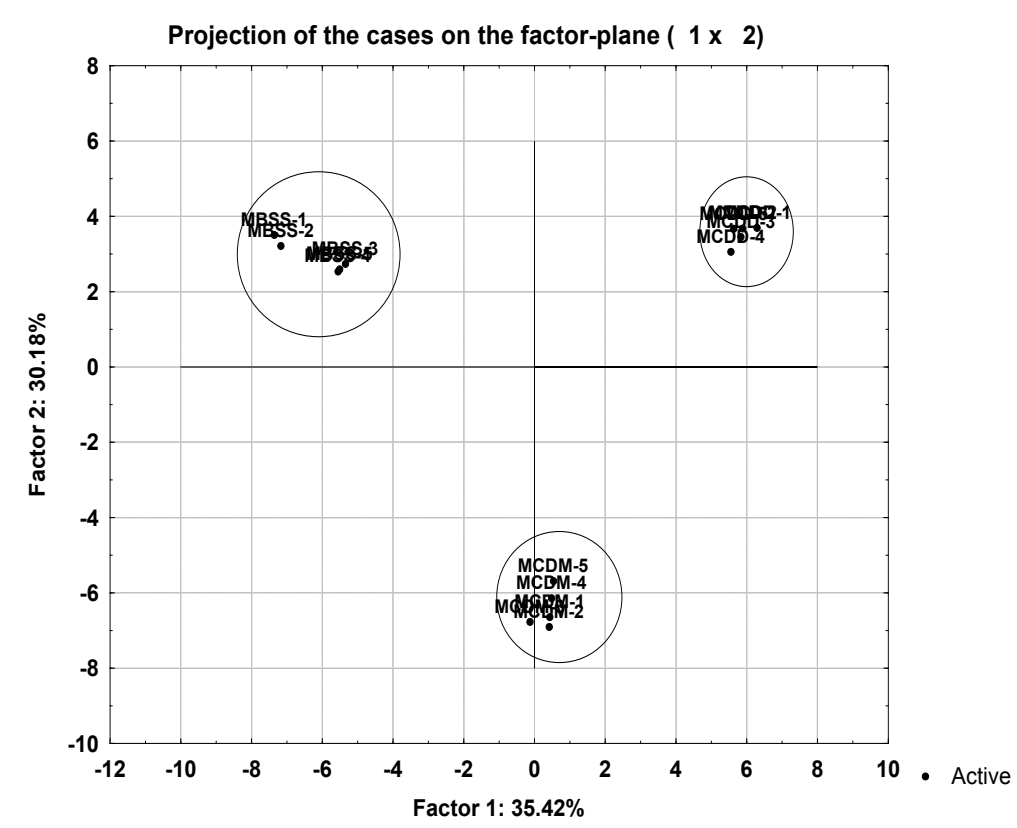

Projection of the cases on the factor-plane $\left(\begin{array}{ll}1 \times 2\end{array}\right)$

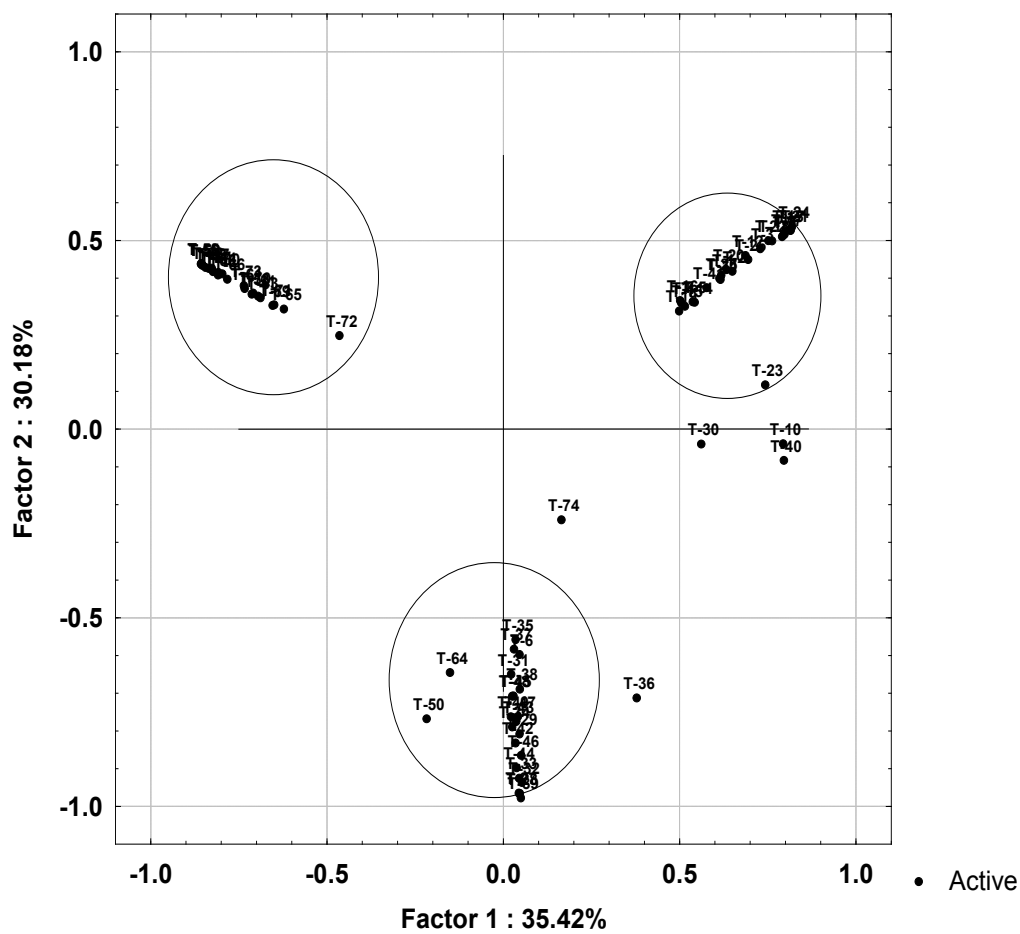

Figure 4: a) PCA biplot showing coordinates of the 15 motor vehicle dust samples plotted along axis 1 and axis 2 .

b) PCA biplot showing coordinates for the 74 recovered taxa plotted along axis 1 and axis 2 . [Serial numbers used for the taxa are T- $1=A$ splenium sp., T-2=Polypodium sp., T-3=Pteris sp., T-4=Athyrium sp., T-5=Peranema sp., T-6=Christella sp., T-7=Pinus sp., T-8=Cryptomeria japonica, T-9=Rhododendron sp., T-10=Shorea robusta, T-11=Primula sp., T-12=Rutaceae, T-13=Betulaceae, T-14=Clematis sp., T-15=Aconitum sp., T-16=Carum copticum, T-17=Asteraceae (cf. Erigeron sp.) T-18=Tithonia sp., T-19=Polygonum sp., T-20=Xanthoxylum sp., T-21=Duabanga sp., T-22=llex sp., T-23=Cheno-ams, T-24=Alnus nepalensis, T-25=Michelia sp., $\mathrm{T}-26=$ Caryophyllaceae, $\mathrm{T}-27=$ Mangifera indica, $\mathrm{T}-28=$ Cocos nucifera, T-29=Alstonia sp., T-30=Poaceae, T-31=Coriandrum sp., T-32=Bombax sp., T-33=Borassus flabellifer, T-34=Syzygium cumini, T-35=Moraceae, T-36=Terminalia sp., T-37=Brassica sp., T-38=Psidium guajava, T-39=Parthenium hysterophorus, T-40=Asteraceae, T-41=Apiaceae, T-42=Peltophorum sp., T-43=Lagerstroemia sp., T-44=Plumeria sp., T-45=Butea sp., T-46=Delonix sp., T-47=Lantana camara, T-48=Eucalyptus sp., T-49=Argemone sp., T-50=Azadirachta indica, T-51=Clerodendrum sp., T-52=Acanthus ilicifolius, T-53=Heritiera fomes, T-54=Xylocarpus sp., T-55=Avicennia sp., T-56=Sonneratia apetala, T-57=Rhizophora mucronata, T-58=Exoecaria agallocha, T-59=Ceriops sp., T-60=Bruguiera sp., T-61=Nypa fruticans, T-62=Phoenix paludosa, T-63=Heliotropium sp., T-64=Barringtonia sp., T-65=Tamarindus indica, T-66=Aegialitis sp., T-67=Caesalpinia sp., T-68=Porteresia sp., T-69=Tamarix sp., T-70=Aegiceras sp., T-71=Kandelia sp., T-72=Derris sp., T-73=Diospyros sp., T-74=Unidentified]. 
boasts of is its varieties of mangoes [41,42]. It is worth mentioning that Murshidabad is well known for both the quality and diversity of mango cultivation. The occurrence of Mangifera indica pollen grains (Figure 6) in considerable frequency suggests the presence of mango orchards along the travelling route taken by the vehicle. A majority of pollen grains of Mangifera indica along with palm trees viz., Cocos nucifera and Borassus flabellifer and common road side weeds viz., Parthenium hysterophorus, Lantana camara demonstrates the route of sampling vehicles i.e., Dhulian-Jangipur-Berhampore-Beldanga in the Murshidabad district.

Darjeeling falls within sub-alpine to tropical moist deciduous vegetation with an abundance of Rhododendron sp. trees. Shorea robusta remains the most prominent species of tropical moist deciduous forests in the foothill region. Cryptomeria japonica is also very common in the Darjeeling Himalaya. The presence of pollen grains of Duabanga sp., Shorea robusta, Michelia sp. in the dust samples from vehicle air filters represents the typical foothill regions of Darjeeling. It is to be noted that Duabanga sp. and Shorea robusta are the most common road side trees in the Tista valley range of the Darjeeling foothills zone $[41,42]$. Dust samples from vehicles on the Siliguri to Darjeeling route yield palynomorphs of coniferous plants viz., Pinus sp., Cryptomeria japonica along with pollen grains of angiospermous plants viz., Alnus nepalensis, Rhododendron sp., Primula sp., Trifolium sp., Clematis sp., Betulaceae, Asteraceae (cf. Erigeron sp.), Tithonia sp., Rutaceae, Shorea robusta and pteridophytic spores of Polypodium sp., Pteris sp., Athyrium sp. that suggest they grow in a sub-alpine to tropical moist deciduous environment in the eastern Himalaya.

\section{Conclusions}

The present study efficiently proves that dust and soot from air filters of motor cars and motor boats may act as an efficient trap of airborne pollen grains and spores of plants characteristically growing in a particular geographical region. Dust from different parts of vehicles

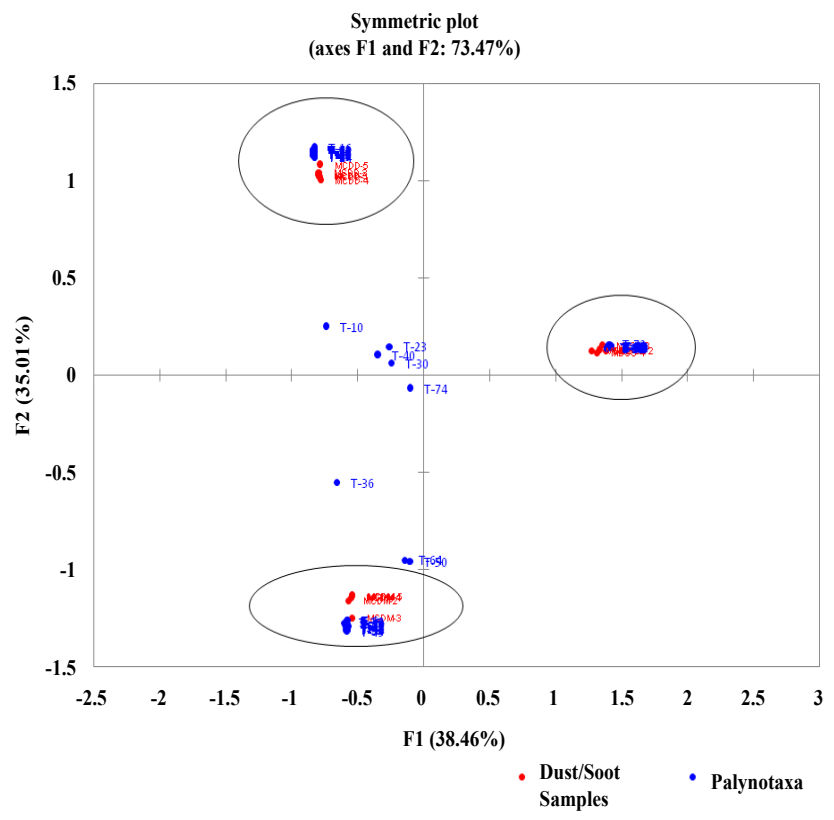

Figure 5: Correspondence analysis symmetric plot of 74 palynotaxa and 15 dust/soot samples along axis 1 and axis 2 .

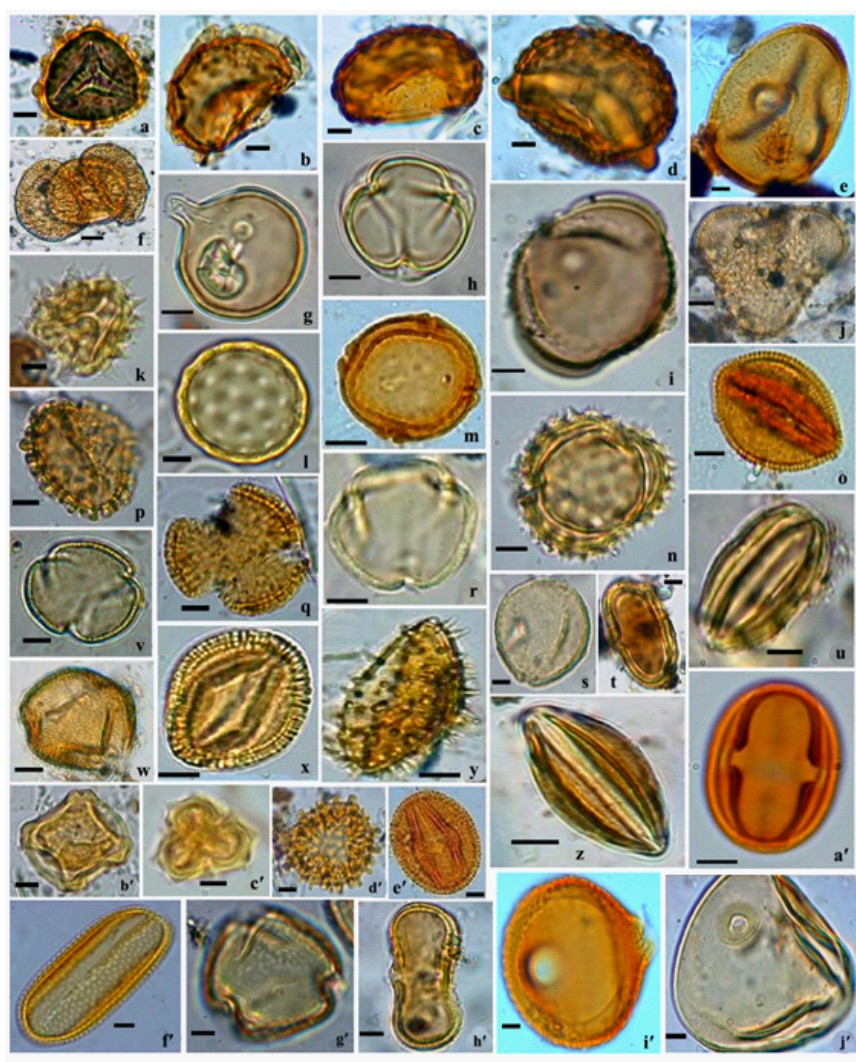

Figure 6: a, Pteris sp., Scale bar $=5 \mu \mathrm{m} ; \mathrm{b}$, Asplenium sp. Scale bar $=5 \mu \mathrm{m}$; c, Polypodium sp. Scale bar $=5 \mu \mathrm{m}$; d, Unidentified type, Scale bar $=5 \mu \mathrm{m}$; e, Aegialitis sp. Scale bar $=5 \mu \mathrm{m} ; \mathrm{f}$, Pinus sp., Scale bar $=10 \mu \mathrm{m} ; \mathrm{g}$, Cryptomeria japonica, Scale bar $=5 \mu \mathrm{m}$; h, Argemone sp., Scale bar $=5 \mu \mathrm{m}$; i, Duabanga sp., Scale bar $=5 \mu \mathrm{m} ; \mathrm{j}$, Bombax sp., Scale bar $=5 \mu \mathrm{m} ; \mathrm{k}$, Asteraceae, Scale bar $=5 \mu \mathrm{m}$; I, Cheno-ams, Scale bar $=5 \mu \mathrm{m} ; \mathrm{m}$, Xylocarpus sp., Scale bar $=5$ $\mu \mathrm{m} ; \mathrm{n}$, Asteraceae, Scale bar $=5 \mu \mathrm{m}$; o, Mangifera indica, Scale bar $=5 \mu \mathrm{m}$; p, llex sp., Scale bar $=5 \mu \mathrm{m} ; \mathrm{q}$, Brassica sp., Scale bar=5 $\mu \mathrm{m} ; \mathrm{r}$, Heritiera fomes, Scale bar $=5 \mu \mathrm{m} ; \mathrm{s}$, Moraceae, Scale bar $=5 \mu \mathrm{m} ; \mathrm{t}$, Carum copticum, Scale bar $=5 \mu \mathrm{m} ; \mathrm{u}$, Terminalia sp., Scale bar $=5 \mu \mathrm{m} ; \mathrm{v}$, Shorea robusta, Scale bar $=5 \mu \mathrm{m} ; \mathrm{w}$, Rutaceae, Scale bar $=10 \mu \mathrm{m} ; \mathrm{x}$, Avicennia sp., Scale bar $=5 \mu \mathrm{m}$; y, Nypa fruticans, Scale bar $=5 \mu \mathrm{m} ; \mathrm{z}$, Unidentified type ,Scale bar=10 $\mu \mathrm{m}$; a', Aegiceras sp., Scale bar $=5 \mu \mathrm{m} ; b^{\prime}$, Alnus nepalensis, Scale bar $=5 \mu \mathrm{m} ; \mathrm{c}^{\prime}$, Parthenium hysterophorus, Scale bar $=5 \mu \mathrm{m} ; d^{\prime}$. Unidentified type, Scale bar $=5 \mu \mathrm{m} ; \mathrm{e}^{\prime}$, Exoecaria sp., Scale bar $=5 \mu \mathrm{m} ; \mathrm{f}^{\prime}$, Acanthus ilicifolius, Scale bar $=5 \mu \mathrm{m} ; \mathrm{g}^{\prime}$, Butea sp., Scale bar $=5 \mu \mathrm{m} ; \mathrm{h}^{\prime}$, Coriandrum sp., Scale bar=5 $\mu \mathrm{m}$; $\mathrm{i}^{\prime}$, Sonneratia apetala, Scale bar $=5 \mu \mathrm{m} ; \mathrm{j}^{\prime}$, Poaceae, Scale bar $=5 \mu \mathrm{m}$.

(mud flap, wheel, seat, tyre, shoe carpet) also capture re-suspended particles as a result of any disturbance of surface deposited pollen grains, animal and biological derived debris [33] but air filters capture only air borne particles which reduces the chance of contamination and indicates the realistic travelling route of a vehicle. This study suggests that analysis of pollen taken from air filters of motor vehicles may help resolve links between people and objects with places and also indicate the localities where the suspected vehicles have travelled. If more than one suspected vehicle involved in forgery, homicide, drug dealing, robbery or hit and run cases, is seized by the police. Palynomorph study from the air filters of those vehicles may be an excellent tool to help identify the vehicle used to commit the offence. Furthermore the data may help identify the season during which the vehicle travelled along a particular route as each of the flowering plants have their own particular flowering season. The data could be used reliably in related legal issues in future forensic investigations. 
Citation: More S, Thapa KK, Bera S (2013) Potential of Dust and Soot from Air-Filters of Motor Vehicle Engines as a Forensic Tool: First Experimental Palynological Approach in India. J Forensic Res 4:177. doi:10.4172/2157-7145.1000177

\section{Acknowledgement}

This work has been funded by University Grants Commission, New Delhi, India under the scheme "Research Fellowship in Science for Meritorious Students" (RFSMS). We acknowledge the help rendered by Dr. Ruby Ghosh, Birbal Sahni Institute of Palaeobotany, Lucknow during statistical analysis of data. Authors also gratefully acknowledge Prof. R. A. Spicer, The Open University, UK and Ms. TEV Spicer for their help during manuscript preparation.

\section{References}

1. Erdtman G (1969) Handbook of Palynology. An Introduction to the study of pollen grains and spores. Hafner Publishing Co., New York 486.

2. Mildenhall DC (1999) Corn flower or corn flour? Canadian Association of Palynologists Newsletter 22: 17-19.

3. Mildenhall DC (1990) Forensic palynology in New Zealand. Rev Paleobot Palynol 64: 227-234

4. Mildenhall DC (2003) Hitched by Hypericum pollen. Canadian Association of Palynologists newsletter 26: 4-6.

5. Mildenhall DC (2004) An example of the use of forensic palynology in assessing an alibi. J Forensic Sci 49: 312-316.

6. Mildenhall DC (2006) Hypericum pollen determines the presence of burglars at the scene of a crime: an example of forensic palynology. Forensic Sci Int 163: 231-235.

7. Mildenhall DC (2006) An unusual appearance of a common pollen type indicates the scene of the crime. Forensic Sci Int 163: 236-240.

8. Stanley EA (1992) Applications of palynology to establish the provenance and travel history of illicit drugs. Microscope 40: 149-152.

9. Stanley EA (1993) Forensic palynology: Federal Bureau of Investigation international symposium on trace evidence. Washington DC: US government printing office.

10. Horrocks M, Coulson SA, Walsh KAJ (1998) Forensic palynology: variation in the pollen content of soil surface samples. J Forensic Sci 43: 320-3.

11. Horrocks M, Coulson SA, Walsh KAJ (1999) Forensic palynology: variation in the pollen content of soil on shoes and in shoeprints in soil. J Forensic Sci 44: 119-22.

12. Horrocks M (2004) Sub-sampling and preparing forensic samples for pollen analysis. J Forensic Sci 49: 1024-1027.

13. Horrocks M, Walsh KAJ (1998) Forensic palynology: assessing the value of the evidence. Rev Palaeobot Palynol 103: 69-74.

14. Horrocks M, Walsh KAJ (1999) Fine resolution of pollen patterns in limited space: differentiating a crime scene and alibi scene seven metres apart. J forensic sci 44: 417-420.

15. Horrocks M, Walsh KA (2001) Pollen on grass clippings: putting the suspect at the scene of the crime. J Forensic Sci 46: 947-949.

16. Walsh KA, Horrocks M (2008) Palynology: its position in the field of forensic science. J Forensic Sci 53: 1053-1060.

17. Bruce RG, Dettmann ME (1996) Palynological analyses of Australian surface soils and their potential in forensic science. Forensic Sci Int 81: 77-94.

18. Milne LA, Bryant VM, Mildenhall DC (2004) Forensic palynology. In: Coyle HM editor. Forensic Botany: Principles and Applications to Criminal Casework, CRC Press, Boca Raton, 217-252.

19. Wiltshire PEJ (1993) Environmental profiling and forensic palynology: background and potential value to the criminal investigator. In Handbook for the national crime and operations faculty with the British association for human identification.

20. Wiltshire PEJ (2004) The value of obtaining palynological information from corpses. Polen 14: 115-116.

21. Wiltshire PE (2006) Consideration of some taphonomic variables of relevance to forensic palynological investigation in the United Kingdom. Forensic Sci Int 163: 173-182.

22. Wiltshire PE (2006) Hair as a source of forensic evidence in murder investigations. Forensic Sci Int 163: 241-248.

23. Wiltshire PE, Black S (2006) The cribriform approach to the retrieval of palynological evidence from the turbinates of murder victims. Forensic Sci Int 163: 224-230.

24. Bryant VM (1989) Pollen: nature's fingerprints of plants 92-111.

25. Bryant VM, Jones JG, Mildenhall DC (1990) Forensic palynology in the United States of America. Palynology 4: 193-208.

26. Bryant VM, Jones JG, Mildenhall DC (1999) 23G-forensic studies in palynology. In Palynology: Principles and Applications (eds. Jansonius, J. and McGregor, D.C.), Am Assoc Strat Palynologists Foundation 3: 957-959.

27. Bryant VM, Jones GD (2006) Forensic palynology: current status of a rarely used technique in the United States of America. Forensic Sci Int 163: 183-197.

28. Bryant VM, Mildenhall DC (1997) Forensic palynology: a new way to catch crooks. Mid-Atlantic Association of Forensic Scientists newsletter 25: 32-46.

29. Eyring MB (1996) Soil pollen analysis from a forensic point of view. Microscope 44: 81-97.

30. Bera SK, Trivedi A, Sharma C (2002) Trapped pollen and spores from spide webs of Lucknow environs. Curr Sci 83: 1580-1585.

31. Song XY, Blackmore S, Bera S, Li CS (2007) Pollen analysis of spider webs from Yunnan, China. Rev Palaeobot Palynol 145: 325-333.

32. Quamar MF, Chauhan MS (2011) Pollen analysis of spider webs from Khedla village, Betul District, Madhya Pradesh. Curr Sci 101(12): 1586-1592.

33. Zavada MS, Mcgraw SM, Miller MA (2007) The role of fabrics as passive pollen collectors in north-eastern United States. Grana 46: 285-291.

34. Bryant VM, Mildenhall DC (1998) Forensic palynology: a new way to catch crooks. In: Bryant VM,Wrenn JW, editors. New developments in palynomorph sampling, extraction and analysis, Am Assoc Stratigraphic Palynologists Found, Contrib Series 33: 145-55.

35. Pain S (1993) Silent witnesses. Kew (Autumn) 22-25.

36. Mildenhall DC (1988) Deer velvet and palynology: an example of the use of forensic palynology in New Zealand. Tuatara 30: 1-11.

37. Brown G, Llewellyn P (1991) Traces of Guilt: Sciences fights Crime in New Zealand. Collins Publishers, Auckland, New Zealand 106.

38. Mildenhall DC (1982) Forensic palynology. In Geological Society of New Zealand Newsletter 58: 25

39. Prain D (1903) The Flora of Sundarbans. Rec Bot Surv Ind 2 (4): 231-270.

40. Naskar KR, Guha Bakshi DN (1987) Mangrove swamps of the Sunderbans (An Ecological Perspective). Naya Prokash, India.

41. Champion HG, Seth SK (1968) A revised survey of the forest types of India Manager of Publications, Government of India 404

42. Puri GS, Meher-Homji VM, Gupta PK, Puri S (1983) Forest ecology phytogeography and forest conservation. Vol. 1. 2nd edition, Oxford and IBH Publ. Co. 340-343. 